\title{
Outbreak of autochthonous canine visceral leishmaniasis in Santa Catarina, Brazil ${ }^{1}$
}

\author{
Mário Steindel2*, Álvaro Menin², Tatiane Evangelista ${ }^{3}$, Patrícia H. Stoco ${ }^{2}$, \\ Mariel A. Marlow ${ }^{2}$, Renata C. Fleith ${ }^{2}$, Celso Pilati ${ }^{4}$ and Edmundo C. Grisard ${ }^{2}$
}

\begin{abstract}
Steindel M., Menin A., Evangelista T., Stoco P.H., Marlow M.A., Fleith R.C., Pilati C. \& Grisard E.C. 2013. Outbreak of autochthonous canine visceral leishmaniasis in Santa Catarina, Brazil. Pesquisa Veterinária Brasileira 33(4):490-496. Departamento de Microbiologia, Imunologia e Parasitologia, Universidade Federal de Santa Catarina, Rua João Pio Duarte Silva s/n, Córrego Grande, Bloco A, Campus Trindade, Florianópolis, SC 88040-900, Brazil.E-mail: mario.steindel@ufsc.br

The present study reports the first outbreak of autochthonous canine visceral leishmaniasis in Florianópolis, Santa Catarina, southern Brazil. Following the report of two cases of CVL, the Control Center of Zoonotic Diseases conducted a serological survey by ELISA and IFAT assays in seven districts of the Santa Catarina Island. Eleven seropositive dogs of autochthonous transmission were used in the present study. Infection by Leishmania sp. was confirmed by parasitological examination of bone marrow, liver, spleen and lymph nodes, culture in Schneider's medium and PCR. Leishmania sp. isolates were characterized by PCR-RFLP and hybridization with specific probes, allowing for the identification of Leishmania infantum. Autochthonous transmission of this disease in an area with high tourist traffic presents a major public health concern and signifies the emergence of an important zoonosis in southern Brazil. Therefore, the implementation of surveillance and control measures is imperative to prevent the spread of the disease among the canine population as well as transmission to the human population.
\end{abstract}

INDEX TERMS: Canine visceral leishmaniasis, Leishmania infantum, zoonosis, neglected diseases, public health.

RESUMO.- [Surto autóctone de leishmaniose visceral canina no Estado de Santa Catarina.] O presente estudo relata o primeiro surto autóctone de leishmaniose visceral canina (LCV) em Florianópolis, Santa Catarina, Brasil. Durante levantamento soro-epidemiológico realizado pelo Centro de Controle de Doenças Zoonóticas (CCZ) envolvendo 2.124 cães, $29(1,37 \%)$ foram soropositivos para VL (ELISA + RIFI). Onze cães positivos por transmissão autóctone foram utilizados no presente estudo. A confirmação da

\footnotetext{
${ }^{1}$ Received on October 8, 2012.

Accepted for publication on February 8, 2013.

${ }^{2}$ Departamento de Microbiologia, Imunologia e Parasitologia, Universidade Federal de Santa Catarina (UFSC), Rua João Pio Duarte Silva s/n, Córrego Grande, Bloco A, Campus Trindade, Florianópolis, SC 88037-001, Brazil. *Corresponding author: mario.steindel@ufsc.br

${ }^{3}$ PET Clínica Veterinária, Rua Moacyr Pereira Junior 11, Lagoa da Conceição, Florianópolis, SC 88062-025.

${ }^{4}$ Departamento de Medicina Veterinária, Centro de Ciências Agroveterinárias, Universidade do Estado de Santa Catarina (UDESC), Av. Luiz de Camões 2090, Conta Dinheiro, Lages, SC 88520-000, Brazil.
}

infecção por Leishmania sp. foi realizada pelo exame parasitológico da medula óssea, fígado, baço e linfonodos, cultura em meio Schneider e PCR. Os isolados de Leishmania sp. foram caracterizados por PCR-RFLP e hibridação com sondas específicas, permitindo a identificação de Leishmania infantum. A transmissão autóctone da LCV em uma área com grande fluxo turístico como Florianópolis representa um preocupante risco à saúde pública e o surgimento de uma importante zoonose no sul do Brasil. Neste contexto, a implementação de medidas de vigilância e controle da doença são fundamentais para evitar a propagação da doença entre a população canina, bem como a transmissão para a população humana.

TERMOS DE INDEXAÇÃO: Leishmaniose visceral canina, Leishmania infantum, zoonose, doenças negligenciadas, saúde pública.

\section{INTRODUCTION}

Visceral leishmaniais (VL) caused by Leishmania (Leishmania) infantum (syn. L. (L.) chagasi) is a zoonotic vector- 
-borne disease endemic in twelve Latin American countries between Mexico and Argentina. The main clinical-pathological manifestations of VL in humans are prolonged fever associated with weight loss, liver and spleen enlargement, pancytopenia, gammaglobulinemia. A high rate of mortality can occur if the disease is not adequately treated (Desjeux 2004). In Brazil, the disease is widespread in both peri-urban and urban areas, and twenty-one out of the twenty-seven states are currently considered endemic for VL with variable transmission rates to humans (Ministério da Saúde 2006). Although higher incidence of human VL is observed in the northeast region, several new endemic areas in the southeast, north and center western regions have been recorded in the past two decades (Werneck 2010). Currently, about $50 \%$ of all cases of human VL occur outside of the northeastern region (Ministério da Saúde 2006). Deforestation, climatic changes and migration of human populations from rural areas to the periphery of towns where people live under precarious housing and sanitation condition are some of the main contributing factors to expansion of the disease (Peterson \& Shaw 2003, Dujardin 2006). Additionally, failures in diagnosis and gaps in scientific knowledge further encumber control efforts and surveillance of zoonotic visceral leishmaniasis (Romero \& Boelaert 2010). Transmission of VL occurs through the bite of the hematophagous female sandfly, Lutzomyia longipalpis, the main known parasite vector in the Americas, which is highly adapted to both peri-urban and urban environments (Lainson \& Rangel 2005). However, there is evidence that $L u$. cruzi, Migonemyia migonei, Lu. evansi, among other flebotomine species may act as vectors of $L$. infantum in Brazil, Colombia and Venezuela (Bejarano et al. 2001, Santos et al. 2003). Although several wild mammals including canids, felids and opossums are involved in the maintenance of the sylvatic transmission cycle of VL, the domestic dog (Canis familiaris) remains the main parasite reservoir and is responsible for maintenance of disease transmission in both peri-urban and urban areas (Braga et al. 1986, Lainson et al. 1990, Travi et al. 1994). In dogs, disease symptoms and pathological changes are diverse and occur in various combinations, which are mainly characterized by fever, weight loss, lymphadenopathy, spleen and liver enlargement (Natami et al. 2000, Lima et al. 2010). The high rate of infected dogs in the presence of competent vectors facilitates VL spreading among dogs and humans (Lainson \& Rangel 2005). Furthering complicating disease control, seropositive dogs without clinical disease signs may present a high skin parasitism, and therefore, may act as an infection source for sandflies (Madeira et al. 2004).

In Brazil, standard measures to control canine visceral leishmaniasis (CVL) include the culling of seropositive dogs and insecticide spraying in the peridomestic environment for vector control (Ministério da Saúde 2006). However, the efficacy of dog culling as a unique control measure for both human and canine visceral leishmaniasis remains controversial (Dietze et al. 1997, Ashford et al. 1998, Courtenay et al. 2002, Grimaldi et al. 2012). In endemic areas, fast dog replacement by owners in houses where infected dogs have been eliminated may play an important role for maintenan- ce of the disease (Nunes et al. 2008). Moreover, the high number of stray dogs and the transport of infected asymptomatic dogs by owners during the vacation season may be a factor of major epidemiological importance for spread of the disease as well (Teske et al. 2002).

Until 2007, the southern region of Brazil was not considered an endemic area for VL, and only a few imported human cases have been reported (Ministério da Saúde 2010). However, in 2008, an outbreak of CVL occurred in the municipality of São Borja in Rio Grande do Sul, the south neighboring state of Santa Catarina (Deboni et al. 2011). A serological survey of 5,430 dogs from 34 municipalities between 2009 and 2010 revealed a CVL seroprevalence of 20.8\% (Tartarotti et al. 2011). In addition, an entomological investigation confirmed the presence of the main known VL vector, $L u$. longipalpis, in seven municipalities of Rio Grande do Sul located on or near the western border with Argentina (Souza et al. 2009, Santos et al. 2011). Concerning human infection, in the two years following this CVL outbreak, eight autochthonous cases of human visceral leishmaniasis, including six adults and two children, from the municipality of São Borja were reported (Deboni et al. 2011). One of these human cases resulted in death. Additionally, in Paraná, the state just north of Santa Catarina, 14 allochthonous cases of CVL have been reported recently in 2009 (Thomaz-Soccol et al. 2009).

Thus, the situation of human cases presenting along side of outbreak of CVL has now occurred in the Rio Grande do Sul, the neighboring state of Santa Catarina. Already cutaneous leishmaniasis, another clinical form of leishmaniasis caused by different species of Leishmania, has emerged in Santa Catarina, with cases having been reported in the Island of Santa Catarina (Marlow et al. 2012). Florianópolis is the state capital and a popular tourist destination, with thousands of tourists visiting the island during the summer season. Several Brazilian visitors which come from both known endemic areas and non-endemic areas for VL bring their dogs with them during the vacation season (December to February), which could potentially allow for further introduction of the parasite or even spreading of VL to other municipalities. Therefore, knowledge on the presence of CVL in this tourist destination and capital municipality is important for controlling the spreading of the disease across the state, as well as, in Brazil and other countries.

Thus, this study was conducted to investigate clinical-pathological features of infected dogs in the first outbreak of autochthonous CVL in the municipality of Florianópolis, State of Santa Catarina, Brazil, as well as to conduct a parasitological characterization of Leishmania parasites isolated from these canines. Epidemiological implications of the outbreak are discussed.

\section{MATERIALS AND METHODS}

\section{Sampling and diagnosis of positive canines}

From July 2010 to October 2011, a canine serological survey using an enzyme linked immunosorbent assay (EIE/LVC/Fiocruz, Brazil) was conducted in seven districts of the municipality of Florianópolis by the Control Center of Zoonotic Diseases (CCZD). 
Positive dogs in the ELISA assay were confirmed by an indirect immunofluorescence antibody test (IFAT). The seropositive dogs were classified based on clinical signs of infection, in accordance with Mancianti et al. (1988). Briefly, the clinical status of dogs were classified by the following criteria: asymptomatic (AL), absence of clinical signs suggestive of infection; oligosymptomatic $(\mathrm{OL})$, presenting up to three clinical signs suggestive of infection, including combinations of lymphadenopathy, opaque bristles, localized alopecia, weight loss and/or dehydration; and symptomatic (SL), presenting characteristic clinical signs of LCV, including cutaneous lesions, furfuraceous eczema, onycogryphosis, opaque bristles, severe loss of weight, apathy, severe dehydration and keratoconjunctivitis. Following euthanasia of seropositive canines in accordance with guidelines set forth by the Brazilian Animal Experimental Collage (COBEA), Federal Law number 11794, clinical samples were collected and transported to the laboratory for complete pathological and parasitological examination.

\section{Parasite culture and histopathological examination}

For Leishmania sp. isolation, aspirates of bone marrow, liver, spleen and lymph nodes were seeded in Schneider medium supplemented with $5 \%$ of heat inactivated calf serum, $10 \mathrm{U} / \mathrm{mL}$ of penicillin, $10 \mu \mathrm{g} / \mathrm{mL}$ of streptomycin and incubated at $26^{\circ} \mathrm{C}$. Positive cultures were bulked in Schneider's medium and parasites were cryopreserved in liquid nitrogen. A part of the biological samples were kept at $-20^{\circ} \mathrm{C}$ for PCR amplification. Smears of bone marrow, liver, spleen and lymph nodes were fixed with methanol, Giemsa stained and examined for amastigote detection under light microscopy using a 100X objective. Samples of liver, spleen, kidney, lymph nodes and ear skin were fixed in $10 \%$ buffered formalin, paraffin-embedded and processed for histological analysis. Serial $5 \mu \mathrm{m}$ tick tissue sections were hematoxylin and eosin stained and, after mounting, slides were analyzed in an Olympus BX-40 microscope and images were digitally recorded.

\section{PCR detection and molecular typing}

DNA extraction from dogs tissue samples and culture of standard Leishmania (V.) braziliensis (MHOM/BR/75/L-2904), L. (L.) amazonensis (IFLA/BR/67/PH8), L. (L.) infantum (LSC-D2) and the Leishmania sp. isolated from dogs was carried out using the standard phenol/chloroform method. After ethanol precipitation, DNA was resuspended in $50 \mu \mathrm{L}$ ultra-pure water and incubated with RNAse $\mathrm{A}(10 \mathrm{mg} / \mathrm{ml})$ at $37^{\circ} \mathrm{C}$ for $1 \mathrm{~h}$ and stored at $-20^{\circ} \mathrm{C}$ until use.

A 120 bp DNA fragment from the conserved region of Leishmania sp. minicircle kDNA was PCR-amplified using primers 150 [5`-GGG (G/T)A GGG GCG TTC T(G/C)C GAA-3`] and 152 [5`-(G/C) $(\mathrm{G} / \mathrm{C})(\mathrm{G} / \mathrm{C})(\mathrm{A} / \mathrm{T}) \mathrm{CT}$ AT(A/T) TTA CAC CAA CCC C-3`] (Volpini et al. 2004). Reactions containing no DNA or DNA from non-infected dog were used as negative controls and DNA of standard L. (V.) braziliensis, $L$. (L.) amazonensis and $L$. (L.) infantum were used as positive controls.

Briefly, amplification was performed in a final volume of $20 \mu \mathrm{L}$ containing $1 \mu \mathrm{M}$ of each primer, $200 \mu \mathrm{M}$ of dNTPs, $1.0 \mathrm{U}$ of Taq DNA polymerase (Invitrogen), $10 \mathrm{mM}$ of Tris- $\mathrm{HCl} \mathrm{pH} \mathrm{8.6,50mM} \mathrm{KCl,} 1.5$ $\mathrm{mM} \mathrm{MgCl}, 10 \mathrm{ng}$ of DNA template. Amplification was carried out in a Mastercycler termocycler (Eppendorf) using a initial denaturation step at $95^{\circ} \mathrm{C} / 5 \mathrm{~min}$, followed by 29 cycles at $95^{\circ} \mathrm{C} / 1 \mathrm{~min}$, $55^{\circ} \mathrm{C} / 30 \mathrm{~s}, 72^{\circ} \mathrm{C} / 10 \mathrm{~s}$ and a final extension step of $5 \mathrm{~min}$. Three $\mu \mathrm{L}$ of each amplification product were resolved in a 3\% agarose gel, ethidium bromide stained and digitally recorded. Also, resolved PCR products were blotted onto nylon membranes (Sigma) and UV cross-linked for hybridization assays. PCR-RFLP was carried out according to Marcondes et al. (2009). Briefly, $5 \mu \mathrm{L}$ of each PCR product was digested at $37^{\circ} \mathrm{C}$ with HaeIII and AvaI (New England
Biolabs) restriction enzymes for $3 \mathrm{~h}$ according to manufacturer's instructions. Restriction fragments were then resolved in $12 \%$ polyacrylamide gels, stained with ethidium bromide and digitally recorded.

The $\sim 120$ bp amplicons from standard L. infantum, L. amazonensis and L. braziliensis strains were isopropanol precipitated, labeled with horseradish peroxidase using the ECL Direct Labeling kit (GE Healthcare) and used as probes in hybridization assays. Southern blot hybridizations were carried out overnight at $42^{\circ} \mathrm{C}$ in gold hybridization buffer (GE Healthcare). Membranes were washed three times in $0.1 \times \mathrm{SSC} / 0.4 \% \mathrm{SDS} / 6 \mathrm{M}$ urea at $42^{\circ} \mathrm{C}$ and twice in $2 \times \mathrm{SSC}$ at room temperature. Hybridization signals were detected using the ECL Western Blotting Substrate (Pierce) and exposure of the membranes to radiographic films.

\section{RESULTS}

From July 2010 to October 2011, a canine serological survey conducted in the Santa Catarina Island identified 29 autochthonous seropositive dogs among 2,124 canines examined. All positive cases were from districts of Canto dos Araçás, Lagoa da Conceição, Costa da Lagoa, Rio Tavares, Campeche and Rio Vermelho (Fig.1). From these 29 seropositive dogs, 11 were further studied and the results are presented in this work. Clinical and diagnostic aspects of canine leishmaniasis cases were presented in (Table 1). At necropsy, one or more of the characteristic symptoms of VL (hepatomegaly with red-brown surface and congested liver parenchyma, splenomegaly, lymphadenopathy and glomerulonephritis) were observed for all dogs. In addition, ulcerative dermatitis with crusted lesions alopecia, onycogryphosis and keratoconjunctivitis was observed in three symptomatic dogs as well.

Leishmania sp. detection by microscopic examination of Giemsa-stained imprints, culture and/or PCR in different biological samples are shown in Table 1. All dogs presented L. infantum amastigotes in bone marrow smears (Fig.2A-B). Culture positivity varied from $63.6 \%$ in spleen to $100 \%$ in bone marrow samples and PCR positivity varied from

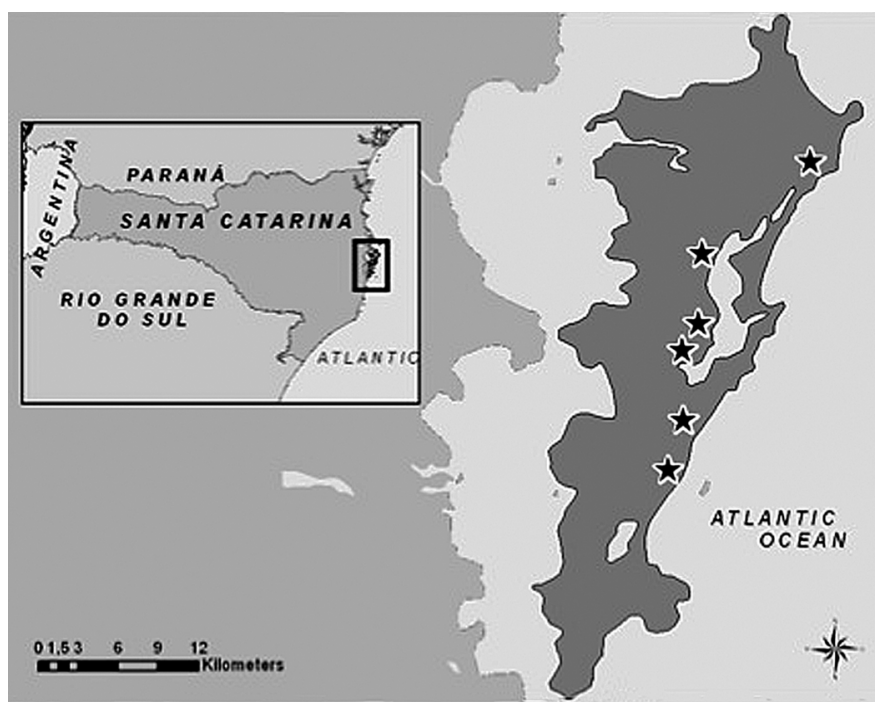

Fig.1. Map of Santa Catarina Island, Santa Catarina State, southern Brazil, showing the distribution of canine visceral leishmaniasis cases. $\star$ District presenting case(s) of canine visceral leishmaniasis. 
Table 1. Clinical and diagnostic aspects of canine leishmaniasis cases from the first LCV outbreak in Florianópolis, Santa Catarina State, Brazil. The clinical groups, parasitological and PCR detection of Leishmania infantum in different tissue samples are shown

\begin{tabular}{|c|c|c|c|c|c|c|c|c|c|c|c|c|c|c|c|}
\hline \multirow[t]{4}{*}{ Dog } & \multirow[t]{4}{*}{ Breed } & \multirow[t]{4}{*}{ Clinical group } & \multicolumn{13}{|c|}{ Leishmania sp. detection } \\
\hline & & & \multirow{2}{*}{\multicolumn{5}{|c|}{$\begin{array}{l}\text { Giemsa stained smear/ } \\
\text { imprints }\end{array}$}} & \multicolumn{5}{|c|}{ Culture } & \multicolumn{3}{|c|}{ kDNA PCR } \\
\hline & & & & & & & & & & & & & & & \\
\hline & & & $\mathrm{Bm}$ & $\mathrm{Lv}$ & $\mathrm{Sp}$ & $\mathrm{Ln}$ & Skin* & $\mathrm{Bm}$ & $\mathrm{Lv}$ & Sp & Ln & $\mathrm{Bm}$ & $\mathrm{Lv}$ & Sp & Ln \\
\hline 1 & Mixed & Oligosymptomatic & + & + & + & - & + & + & + & + & + & + & + & + & + \\
\hline 2 & Mixed & Asymptomatic & + & - & - & - & + & + & + & + & + & + & + & + & + \\
\hline 3 & Mixed & Oligosymptomatic & + & - & + & + & - & + & + & + & + & + & + & + & + \\
\hline 4 & Pitt bull & Asymptomatic & + & + & - & - & + & + & + & - & - & + & + & - & - \\
\hline 5 & Mixed & Symptomatic & + & + & + & + & + & + & + & + & + & + & + & + & + \\
\hline 6 & Mixed & Oligosymptomatic & + & - & - & + & + & + & - & - & - & + & - & - & - \\
\hline 7 & Rottweiler & Asymptomatic & + & + & + & - & + & + & + & + & + & + & + & - & + \\
\hline 8 & Mixed & Symptomatic & + & - & - & - & + & + & - & - & + & + & + & + & + \\
\hline 9 & Dachshund & Oligosymptomatic & + & + & - & + & + & + & + & - & - & + & + & + & + \\
\hline 10 & Mixed & Symptomatic & + & + & + & - & + & + & + & + & + & + & + & + & + \\
\hline 11 & Mixed & Asymptomatic & + & - & + & + & + & + & + & + & + & + & + & + & + \\
\hline
\end{tabular}

$72.7 \%$ in spleen and $100 \%$ in bone marrow, totaling 11 isolated strains (Table 1).

Histopathological analysis of skin showed perivascular and perifollicular granulomatous exfoliative/ulcerative

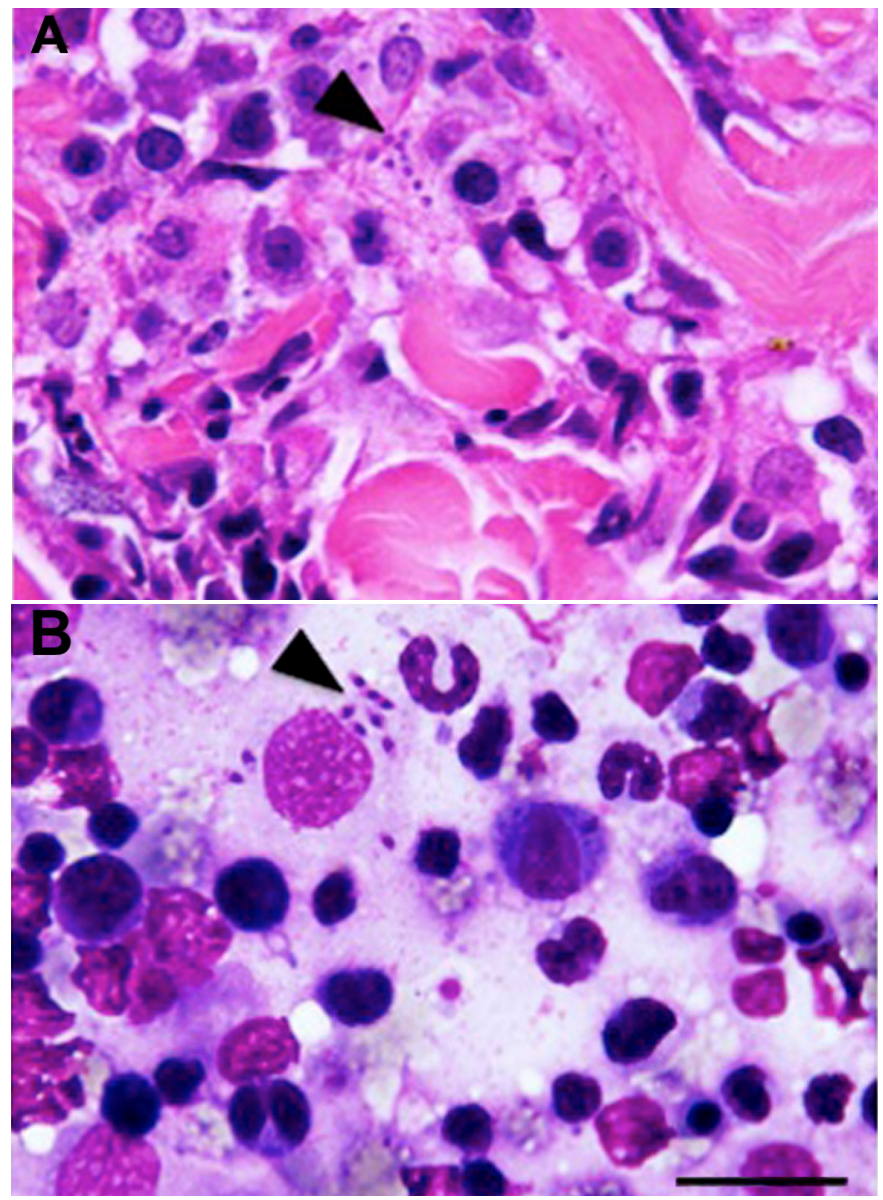

Fig.2. (A) Representative histopathology of skin from asymptomatic dog stained with hematoxylin and eosin showing Leishmania infantum amastigotes in the cytoplasm of skin macrophages. (B) Representative bone marrow smear of positive dog stained with Giemsa stained. Note amastigotes in the cytoplasm of monocytes $/$ macrophages. Scale bar $=50 \mu \mathrm{m}$. dermatitis with an intense lymphohistiocytic infiltrate in the superficial and deep dermis and epidermal hyperkeratinization. Lymphoid tissue, including mandibular, parotid, retropharyngeal, tracheobronchial, mediastinal, iliac, sciatic, pre-scapular and pre-crural lymph nodes and spleen presented a diffuse mononuclear inflammation and hyperplasia of lymphoid follicles with predominance of plasmocytes. Moreover, red pulp and follicular hyperplasia with high macrophage proliferation and presence of megakaryocytes in the spleen were observed as well. A diffuse lymphohistoplasmocytic mononuclear infiltrate with greater intensity in the portal spaces, vacuolar degeneration of the hepatocyte cytoplasm, and hyperplasia and hypertrophy of Kupffer cells was observed in the livers. Mesangioproliferative and membranoproliferative glomerulonephritis and tubular degeneration were observed in the kidneys.

All isolated strains were positive for specific PCR amplification of the Leishmania sp. kDNA minicircle fragment ( $\sim 120 \mathrm{bp}$ ). HaeIII digestion of the PCR product from L. (V.) braziliensis resulted in two fragments ( 80 and $40 \mathrm{bp}$ ), four fragments for L. (L.) infantum (120, 80, 60 and $40 \mathrm{bp})$ and no digestion for $L$. (L.) amazonensis. Digestion of the $L$. (L.) amazonensis amplicon with AvaI resulted in two fragments (80 and $40 \mathrm{bp}$ in size), while L. (L.) braziliensis and L. (L.) infantum products remained uncut. Comparative analysis of the restriction profile obtained for all Leishmania sp. isolated from dogs with the profiles of the reference strains allowed for the identification of the isolates as $L$. (L.) infantum (Fig.3A). This result was further confirmed by Southern blot hybridization, using L. amazonensis, L. braziliensis and L. infantum specific probes (Fig.3B).

\section{DISCUSSION}

Here we report the first outbreak of CVL in the Santa Catarina Island, Florianópolis municipality where a seroprevalence of $1.4 \%$ for Leishmania infantum was confirmed among 2,124 examinated dogs. The usually high rate of seropositivity in dog population varies across the different regions in Brazil, with seroprevalences ranging from $4.2 \%$ 
A
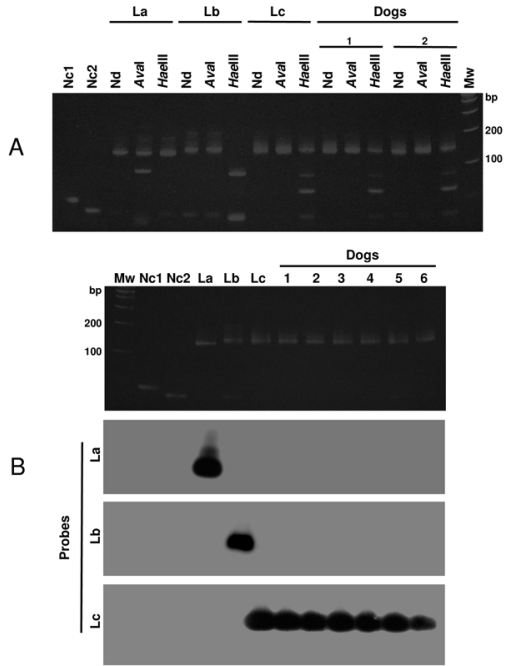

Fig.3. (A) Representative PCR-RFLP profiles of Leishmania isolated from naturally infected dogs, and (B) hybridization of the 120 bp PCR product with distinct Leishmania sp. probes. MW = molecular weight marker (100 bp ladder); Nc1 = no DNA, and Nc2 = DNA of non-infected dog (negative controls); $\mathrm{Nd}=$ Non-digested PCR product; AvaI = PCR product digested with AvaI; HaeIII = PCR product digested with HaeIII; La = L. amazonensis; $\mathrm{Lb}=$ L. braziliensis; $\mathrm{Li}=$ L. infantum; 1-6 = Canine cases.

in Paracatu, Minas Gerais (Dias et al. 2011), 3.4\% to 8.4\% in Cuiabá, Mato Grosso (Almeida et al. 2009, Mestre \& Fontes 2007), 9.7\% in Montes Claros, Minas Gerais (França-Silva et al. 2003), $11.3 \%$ in Rio Grande do Norte (Queiroz et al. $2009)$ to $20.8 \%$ in municipalities of the western region of Rio Grande do Sul (Tartarotti et al. 2011) and 40.3\% in Paulista, Pernambuco (Dantas-Torres et al. 2006). After the first cases of CVL were reported to the municipality health surveillance authorities, the CCZD have continued to monitor the focus area and confirmed the parasite transmission in the Santa Catarina Island by reporting two autochthonous cases (Figueiredo et al. 2012). Thus, a parasite vector must be currently present on the island for this transmission to occur. In contrast with the Rio Grande do Sul state where the classical L. infantum vector, Lutzomyia longipalpis, was captured in several municipalities, no records on the presence of Lu. longipalpis in the Santa Catarina Island has been reported. Other phlebotomine species as $L u$. cruzi has been incriminated as vector of L. infantum in some regions of Mato Grosso do Sul state (Santos et al. 1998, Pita-Pereira et al. 2008) and Migonemyia migonei in Pernambuco state (Carvalho et al. 2010). In Santa Catarina Island, a phlebotomine survey conducted in 2010 at the CVL focus area identified four sandfly species (Brumptomyia sp., $L u$. fischeri, Mg. migonei and Lu. neivai). Detection of Leishmania infection by PCR of the 423 sandfly females tested showed that only one pool of Lu. neivai was positive, but the Leishmania species was not determined (Dias et al. 2010). Thus, the occurrence of VL transmission among dogs in the absence of the classic vector Lu. longipalpis, suggests other sandfly species may be involved in L. infantum transmission cycle in the Santa Catarina Island. In a previous study in a cutaneous leishmaniasis focus area in the municipality of Piçarras, the natural infection of Lu. neivai by Leishmania of Viannia subgenus was reported and reinforces this hypothesis (Marcondes et al. 2009).

From the 29 autochthonous cases of CVL, 11 from the districts of Canto dos Araçás, Canto da Lagoa, Rio Tavares and Campeche were further studied. Clinical evaluation of these 11 dogs showed that four (36.3\%) were asymptomatic. In a study in the metropolitan area of Natal and in a rural area of São Miguel in the Rio Grande do Norte state, between $60 \%$ and $83.3 \%$ of dogs with positive serology for VL were asymptomatic (Queiroz et al. 2009). In Paracatu, Minas Gerais, 5\% out of 267 dogs with positive serology for VL were asymptomatic (Dias et al. 2011). The presence of L. infantum amastigotes in the skin of asymptomatic seropositive dogs has been reported previously (Lainson \& Rangel 2005, Madeira et al. 2005, Dias et al. 2011). In this study, parasitological examination showed the presence of amastigotes in bone marrow (100\%), spleen and liver (54.5\%), lymph nodes (45.4\%) and skin (90.9\%) in all asymptomatic dogs. This high parasitism of skin may facilitate the sandfly infection and therefore improve Leishmania sp. transmission. A comparison of parasite macrophage load from various tissues including skin, lymph nodes, liver and spleen of asymptomatic and symptomatic dogs did not show differences as formerly reported (Lima et al. 2010). Moreover, infection rates of Lu. longipalpis which fed on asymptomatic, oligosymptomatic and symptomatic dogs did not show statistical differences, but when sandflies were fed on symptomatic dogs a higher vector infection rate (5x) was found (Michalsky et al. 2007). Asymptomatic dogs are not detected by clinical examination and therefore may be stay for long periods undiagnosed. This fact may be relevant for VL maintenance in endemic areas, as well as in the spreading of the disease to non-endemic areas by companion dogs, especially if competent sand flies species are present.

Although four seropositive dogs were asymptomatic at clinical inspection, at necropsy, all dogs showed gross pathology of the disease, including lymphadenopathy, hepatomegaly, splenomegaly and glomerulonephritis. In symptomatic cases, pulmonary edema and petechiae in the renal cortex were observed at necropsy as well. Histopathological examination revealed an intense infiltrate of macrophages in different organs and tissues with a variable number of amastigotes in the macrophage cytoplasm, particularly in the bone marrow, spleen, lymph nodes, skin and liver. All infected dogs were adult with age varying from two to 10 years. However, the severity of histopathological lesions and parasite load in skin and bone marrow of CVL cases in this study, particularly those from asymptomatic animals, is important due to a higher transmissibility of the parasite. Asymptomatic cases may represent stabilized forms or cases in which there is control of infection by an efficient host immune response (Pinelli et al. 1994, Martinez-Moreno et al. 1995, Natami et al. 2000, Madeira et al. 2004). Our findings are similar to those previously observed in other studies in endemic areas for CVL in Brazil (Gontijo \& Melo 2004, Oliveira et al. 2010, Lima et al. 2010 ) and others countries (Natami et al. 2000, Faye et al. 2010). 
The high frequency of asymptomatic L. infantum carriers and fast dog replacement makes control of VL difficult. In Araçatuba municipality, São Paulo from August 2002 to July 2004 a total of 578 seropositive dogs were eliminated; however, a mean interval of $38.8 \%$ dog replacement in four months was observed (Nunes et al. 2008). According to this study, in a 2.5 years interval, half of the replaced dog population became positive, suggesting the maintenance of VL in the area. The fast dog population turnover, especially by puppies which are more susceptible to the parasite, may make the control the VL transmission difficult. Since the Santa Catarina Island is a highly frequented holiday destination for both Brazilian and international tourists, a permanent monitoring program for CVL needs to be implemented. No data concerning dog replacement in the focus area exists presently. Additionally, as not all localities were investigated, the presence of positive animals in other regions of the Island is unknown. Mapping of cases in this study has already demonstrated CVL is distributed across the Island and not focused to any specific area. The high prevalence of positive animals with high cutaneous parasite load is of utmost importance, since these animals could be act as silent reservoirs, which remain for longer periods in the transmission cycle. On the other hand, a more detailed composition of the phlebotomine fauna is necessary in order to identify potential species for L. infantum transmission. VL outbreaks in the canine population are known to precede the occurrence of disease in humans (Deboni et al. 2011). To date, no transmission of VL to humans related to this CVL outbreak in the Santa Catarina Island has been confirmed.

Visceral leishmaniasis is a growing public health problem in Brazil, where twenty-one out of twenty-seven states present active transmission (Ministério da Saúde 2012). It is well established that dogs play a central role in the maintenance and expansion of L. infantum infection and transmission depending on several ecological and epidemiological features, especially on the presence of competent vector species and susceptible mammalian hosts. This work confirms and provides an evaluation of the clinical and histopathological features of the first outbreak of CVL Santa Catarina Island, Santa Catarina, Brazil. The presence of CVL in an area with high tourist traffic is of concern for resident dog owners, veterinarians, and public health officials alike. The availability of data only from a limited study area and the presence of asymptomatic cases indicate the need for a complete active surveillance program. Additionally, the lack of an incriminated vector makes the control of the disease spreading increasingly difficult. Controlling of the CVL situation in the municipality is imperative for preventing the spread of the disease to humans.

Acknowledgments.- The authors would like to thank CCZ/DIVE for allowing to collect the samples used in this study, and C.N. Yamanaka and A. Fernandes for their technical assistance. P.H.S., M.M. and R.C.F. are recipients of CAPES or CNPq Scholarships (Brazilian Government Agencies). The study was funded by CNPq, CAPES and FINEP (Brazilian Government Agencies). Funders have no role on study design, data generation and analysis, decision to publish, or preparation of the manuscript.

\section{REFERENCES}

Almeida A.B.P.F., Faria R.P., Pimentel M.F.A., Dahroug M.A.A., Turbino N.C. M.R. \& Souza V.R.F. 2009. Inquérito soroepidemiológico de leishmaniose canina em áreas endêmicas de Cuiabá, estado de Mato Grosso. Revta Soc. Bras. Med. Trop. 42:156-159.

Ashford D.A., David J.R., Freire M., David R., Sherlock I., Eulálio M.C., Sampaio D.P. \& Badaro R. 1998. Studies on control of visceral leishmaniasis: impact of dog control on canine and human visceral leishmaniasis in Jacobina, Bahia, Brazil. Am. J. Trop. Med. Hyg. 59:53-57.

Bejarano E.E., Uribe S., Rojas W. \& Velez I.D. 2001. Presence of Lutzomyia evansi a vector of American visceral leishmaniasis, in an urban area of the Colombian Caribbean coast. Trans. R. Soc. Trop. Med. Hyg. 95:27-28.

Braga R.R., Lainson R., Shaw J.J., Ryan L. \& Silveira F.T. 1986. Leishmaniasis in Brazil. XXII: characterization of Leishmania from man, dogs and the sandfly Lutzomyia longipalpis (Lutz et Neiva, 1912) isolated during an outbreak of visceral leishmaniasis in Santarem, Para State. Trans. R. Soc. Trop. Med. Hyg. 80:143-145.

Carvalho M.R., Valença H.F., Silva F.J., Pita-Pereira D., Araújo T.P., Britto C., Brazil R.P. \& Brandão Filho S.P. 2010. Natural Leishmania infantum infection in Migonemyia migonei (França, 1920) (Diptera: Psychodidae: Phlebotominae) the putative vector of visceral leishmaniasis in Pernambuco State, Brazil. Acta Trop. 116(1):108-110.

Courtenay O., Quinnell R.J., Garcez L.M., Shaw J.J. \& Dye C. 2002. Infectiousness in a cohort of Brazilian dogs: why culling fails to control visceral leishmaniasis in areas of high transmission. J. Infect. Dis. 186:13141320.

Dantas-Torres F., de Brito M.E.F. \& Brandão-Filho S.P. 2006. Soroepidemiological survey on canine leishmaniasis among dogs from an urban area of Brazil. Vet. Parasitol. 140:54-60.

Deboni S.C., Barbosa M. \& Ramos R.R. 2011. Leishmaniose Visceral no Rio Grande do Sul. Bolm Epidemiol. 13(1):1-3.

Desjeux P. 2004. Leishmaniasis: current situation and new perspectives. Comp. Immunol. Microbiol. Infect. Dis. 27:305-318.

Dias S.E. 2010. Detecção de infecção por Leishmania spp. em flebotomíneos coletados na cidade de Florianópolis, SC. Relatório Técnico-Científico, Centro de Referência em Competência Vetorial de Flebotomíneos, Laboratório de Leishmanioses/CPqRR/Fiocruz, Belo Horizonte, MG. 6p.

Dias E.S., Regina-Silva S., França-Silva J.C., Paz G.F., Michalsky E.M., Araújo S.C., Valadão J.L., de Oliveira Lara-Silva F., de Oliveira F.S., Pacheco R.S. \& Fortes-Dias C.L. 2011. Eco-epidemiology of visceral leishmaniasis in the urban area of Paracatu, State of Minas Gerais, Brazil. Vet. Parasitol. 176:101-111.

Dietze R., Barros G.B., Teixeira L., Harris J., Michelson K., Falqueto A. \& Corey R. 1997. Effect of eliminating seropositive canines on the transmission of visceral leishmaniasis in Brazil. Clin. Infect. Dis. 25:1240-1242.

Dujardin J.C. 2006. Risk factors in the spread of leishmaniasis: towards integrated monitoring? Trends Parasitol. 22:4-6.

Faye B., Banuls A.L., Bucheton B., Dione M.M., Bassanganam O., Hide M., Dereure J., Choisy M., Ndiaye J.L., Konate O., Claire M., Senghor M.W., Faye M.N., Sy L., Niang A.A., Molez J.F., Victoir K., Marty P., Delaunay P., Knecht R., Mellul S., Diedhiou S. \& Gaye O. 2010. Canine visceral leishmaniasis caused by Leishmania infantum in Senegal: risk of emergence in humans? Microbes Infect. 12:1219-1225.

Figueiredo F.B., Lima Júnior F.E.F., Tomio J.E., Indá F.M.C., Corrêa G.L.B. \& Madeira M.F. 2012. Leishmaniose Visceral Canina: Dois casos autóctones no município de Florianópolis, Estado de Santa Catarina. Acta Scient. Vet. 40:1026-1029.

Gontijo C.M.F. \& Melo M.N. 2004. Leishmaniose Visceral no Brasil. Revta Bras. Epidemiol. 7:338-349.

Grimaldi G.J., Teva A., Santos C.B., Ferreira A.L. \& Falqueto A. 2012. The effect of removing potentially infectious dogs on the numbers of canine Leishmania infantum infections in an endemic area with high transmission rates. Am. J. Trop. Med. Hyg. 86(6):966-71.

Lainson R., Dye C., Shaw J.J., MacDonald D.W., Courtenay O., Souza A.A.A. \& Silveira F.T. 1990. Amazonian visceral leishmaniasis-distribution of the vector Lutzomyia longipalpis (Lutz et Neiva) in relation to the fox Cer- 
docyon thous (Linn.) and the efficiency of this reservoir host as a source of infection. Mem. Inst. Oswaldo Cruz 85:135-137.

Lainson R. \& Rangel E.F. 2005. Lutzomyia longipalpis and the eco-epidemiology of American visceral leishmaniasis, with particular reference to Brazil: a review. Mem. Inst. Oswaldo Cruz 100:811-827.

Lima L.R., Carneiro L.A., Campos M.B., Chagas E.J., Laurenti M.D., Corbett C.E.P., Lainson R. \& Silveira F.T. 2010. Canine Visceral Leishmaniasis due to Leishmania (L.) infantum chagasi in Amazonian Brazil: comparison of the parasite density from the skin, lymph node and visceral tissues between symptomatic and asymptomatic, seropositive dogs. Revta Inst. Med. Trop. 52:259-265.

Madeira M.F., Schubach A.O., Schubach T.M., Serra C.M., Pereira S.A., Figueiredo F.B., Confort E.M., Quintella L.P. \& Marzochi M.C. 2005. Is Leishmania (Viannia) braziliensis preferentially restricted to the cutaneous lesions of naturally infected dogs? Parasitol. Res. 97:73-76.

Madeira M.F., Schubach A.O., Schubach T.M.P., Leal C.A. \& Marzochi M.C.A. 2004. Identification of Leishmania (Leishmania) chagasi isolated from healthy skin of symptomatic and asymptomatic dogs seropositive for leishmaniasis in the Municipality of Rio de Janeiro, Brazil. Braz. J. Infect. Dis. 8:440-444.

Mancianti F., Gramiccia M., Gradoni L. \& Pieri S. 1988. Studies on canine leishmaniasis control: evolution of infection of different clinical forms of canine leishmaniasis following antimonial treatment. Trans. R. Soc. Trop. Med. Hyg. 82:566-567.

Marcondes C.B., Bittencourt I.A., Stoco P.H., Eger I., Grisard E.C. \& Steindel M. 2009. Natural infection of Nyssomyia neivai (Pinto, 1926) (Diptera: Psychodidae, Phlebotominae) by Leishmania (Viannia) spp. in Brazil. Trans. R. Soc. Trop. Med. Hyg. 103:1093-1097.

Marlow M.A., Mattos M.S., Makowiecky M.E., Eger I., Rossetto A.L., Grisard E.C. \& Steindel M. 2013. Divergent profile of emerging cutaneous leishmaniasis in subtropical Brazil: new endemic areas in the southern frontier. Plos One (Accepted for publication)

Martinez-Moreno A., Moreno T., Martinez-Moreno F.J., Acosta I. \& Hernandez S. 1995. Humoral and cell mediated immunity in natural and experimental canine leishmaniasis. Vet. Immun. Immunopathol. 48:209-220.

Mestre G.L.C. \& Fontes C.J.F. 2007. A expansão da epidemia da leishmaniose visceral no Estado de Mato Grosso, 1998-2005. Revta Soc. Bras. Med. Trop. 40(1):42-48.

Michalsky E.M., Rocha M.F., Lima A.C.V.M.R., França-Silva J.C., Pires M.Q., Oliveira F.S., Pacheco R.S., Santos S.L., Barata R.A., Romanha A.J., Fortes-Dias C.L. \& Dias E.S. 2007. Infectivity of seropositive dogs, showing different clinical forms of leishmaniasis, to Lutzomyia longipalpis phlebotomine sand flies. Vet. Parasitol. 147:67-76.

Ministério da Saúde 2006. Manual de Vigilância e Controle da Leishmaniose Visceral. Brasília, DF. 122p.

Ministério da Saúde 2010. Nota técnica conjunta da Secretaria de Vigilância em Saúde do Ministério da Saúde e da Secretaria de Estado da Saúde do Rio Grande do Sul sobre a situação da Leishmaniose Visceral na fronteira do Estado do Rio Grande do Sul com a Argentina. <http://portal. saude.gov.br/portal/arquivos/pdf/nota_tec_front_br_argentina_lv_final_ses_rs.pdf>

Ministério da Saúde 2012. Casos confirmados de Leishmaniose Visceral nas Grandes Regiões e Unidades Federadas do Brasil (1990 a 2010). $<$ http://portal.saude.gov.br/portal/saude/profissional/visualizar_texto.cfm?idtxt=31937>

Natami A., Sahibi H., Lasri S., Boudouma M., Guessouss-Idrrissi N. \& Rhalem A. 2000. Serological, clinical and histopathological changes in naturally infected dogs with Leishmania infantum in the khemisset province, Morocco Vet. Res. 31:355-363.
Nunes C.M., de Lima V.M.F., de Paula H.B., Perri S.H.V., de Andrade A.M., Dias F.E. \& Burattini N.M. 2008. Dog culling and replacement in an area endemic for visceral leishmaniasis in Brazil. Vet. Parasitol. 153:19-23.

Oliveira L.C.P., Araújo R.R., Alves C.R., Mouta-Confort E., López J.A. \& Mendonça-Lima F.W. 2010. Seroprevalence and risk factors for canine visceral leishmaniasis in the endemic area of Dias D’Ávila, State of Bahia, Brazil. Revta Soc. Bras. Med. Trop. 43:400-404.

Peterson A.T. \& Shaw J. 2003. Lutzomyia vectors for cutaneous leishmaniasis in Southern Brazil: ecological niche models, predicted geographic distributions, and climate change effects. Int. J. Parasitol. 33(9):919-931.

Pinelli E., Killick-Kendrick R., Wagenaar J., Benadina W., Del Real G. \& Ruitenberg J. 1994. Cellular and humoral immune responses in dogs experimentally and naturally infected with Leishmania infantum. Infect. Immun. 62:229-235.

Pita-Pereira D., Cardoso M.A.B., Alves C.R., Brazil R.P. \& Britto C. 2008. Detection of natural infection in Lutzomyia cruzi and Lutzomyia forattinii (Diptera: Psychodidae: Phlebotominae) by Leishmania infantum chagasi in an endemic area of visceral leishmaniasis in Brazil using a PCR multiplex assay. Acta Trop. 107:66-69.

Queiroz P.V.S., Monteiro G.R.G., Macedo V.P.S., Rocha M.A.C., Batista L.M.M., Queiroz J.W., Jerônimo S.M.B. \& Ximenes M.F.F.M. 2009. Canine visceral leishmaniasis in urban and rural areas of Northeast Brazil. 86(2):267273.

Romero G.A.S. \& Boelaert M. 2010. Control of visceral leishmaniasis in Latin America. A systematic review. PLoS. Negl. Trop. Dis. 4(1):e584, 1-17.

Santos E., Silva F.D. \& Souza G.D. 2011. Vigilância entomológica. Bolm Epidemiol. 13(1):1-3.

Santos S.O., Arias J.R., de Paiva H.M., Furlan M.B., Ferreira W.F., Pereira C. \& Ferreira L. 2003. The presence of Lutzomyia longipalpis in a focus of American visceral leishmaniasis where the only proven vector is Lutzomyia cruzi. Corumba, Mato Grosso do Sul State. Revta Soc. Bras. Med. Trop. 36:633-634.

Santos S.O., Arias J., Ribeiro A.A., Hoffmann M.P., Freitas R.A. \& Malacco M.A.F. 1998. Incrimination of Lutzomyia cruzi as a vector of American visceral leishmaniasis. Med. Vet. Entomol. 12:315-317.

Souza G.D., Santos E. \& Andrade-Filho J.D. 2009. The first report of the main vector of visceral leishmaniasis in America, Lutzomyia longipalpis (Lutz et Neiva) (Diptera: Psychodidae: Phlebotominae), in the State of Rio Grande do Sul, Brazil. Mem. Inst. Oswaldo Cruz 104:1181-1182.

Tartarotti A.L., Doninil M.A., Anjos C. \& Ramos R.R. 2011. Vigilância de reservatórios caninos. Bolm Epidemiol. 13(1):3-6.

Teske E., Van Knapen F., Beijer E.G.M. \& Slappendel R.J. 2002. Risk of Infection with Leishmania spp. in the Canine Population in the Netherlands. Acta Vet. Scand. 43(4):195-201.

Thomaz-Soccol V., Castro E.A., Navarro I.T., Farias M.R., Souza L.M., Carvalho Y., Bispo S., Membrive N.A., Minozzo J.C., Truppel J., Bueno W. \& Luz E. 2009. Allochthonous cases of canine visceral leishmaniasis in Paraná, Brazil: epidemiological implications. Revta Bras. Parasitol. Vet. 18(3):46-51.

Travi B.L., Jaramillo C., Montoya J., Segura I., Zea A., Gonçalves A. \& Velez I.D. 1994. Didelphis marsupialis, an important reservoir of Trypanosoma (Schizotrypanum) cruzi and Leishmania (Leishmania) chagasi in Colombia. Am. J. Trop. Med. Hyg. 50:557-565.

Volpini A.C., Passos V.M., Oliveira G.C. \& Romanha A.J. 2004. PCR-RFLP to identify Leishmania (Viannia) braziliensis and L. (Leishmania) amazonensis causing American cutaneous leishmaniasis. Acta Trop. 90:31-37.

Werneck G.L. 2010. Geographic spread of visceral leishmaniasis in Brazil. Cad. Saúde Pública 26(4):644-645. 